\title{
Alternative Organic Liquid Fertilizer from Meatball Water Decoction with Banana Humps Activator
}

\author{
S. D. Cahyani, N. R. Amalia, A. H. Achmad, M. Hilmi, and D. Triasih \\ Study Program Livestock Product Processing Technology, Politeknik Negeri Banyuwangi \\ Jl. Raya Jember Km. 13, Labanasem, Kabat, Banyuwangi \\ Corresponding Author: selvydwicahyani01@gmail.com
}

\begin{abstract}
This study aimed to determine the effect of the use of EM4 and Local Microorganism (LM) activators from banana hump (Kepok banana, Raja banana, and Ambon banana) on the manufacture of organic liquid fertilizer derived from waste meatball water stew. The research method used in this study was Completely Randomized Design (CRD) consisting of 4 treatments and three replications, namely: P1 EM4, P2 (Local Microorganism from Kepok banana hump ), P2 (Local Microorganism from Ambon banana hump), P3 (Local Microorganism from Raja banana hump). In this study testing the levels of Nitrogen, Phosphorus, Potassium, Carbon, and $\mathrm{pH}$ levels in organic liquid fertilizer from boiled meatball water. The data obtained from this study were analyzed using Complete Randomized Design and Duncan's advanced test. The results of the addition of EM4 activator and banana hump MOL on the manufacture of organic liquid fertilizer from meatball decoction water showed no significant effect $(\mathrm{P}>0.05)$ on $\mathrm{N}, \mathrm{K}$, and $\mathrm{pH}$ levels on fertilizers. The results showed a significant effect $(\mathrm{P}$ $<0.05$ ) on the $\mathrm{P}$ content of fertilizer. The highest $\mathrm{C}$ content was found in $\mathrm{P} 2$, while the highest $\mathrm{C} / \mathrm{N}$ ratio was found in $\mathrm{P} 0$.
\end{abstract}

Keywords: activator, EM4, Local Microorganism, Organic Liquid Fertilizer

\begin{abstract}
ABSTRAK
Penelitian ini bertujuan untuk mengetahui pengaruh penggunaan EM4 dan Mikroorganisme Lokal (LM) aktivator dari punuk pisang (pisang Kepok, pisang Raja, dan pisang Ambon) pada pembuatan pupuk cair organik yang berasal dari limbah rebusan bakso air. Metode penelitian yang digunakan dalam penelitian ini adalah Rancangan Acak Lengkap (RAL) yang terdiri dari 4 perlakuan dan tiga ulangan, yaitu: P1 EM4, P2 (Mikroorganisme Lokal dari punuk pisang Kepok), P2 (Mikroorganisme Lokal dari punuk pisang Ambon), P3 (Lokal Mikroorganisme dari punuk pisang Raja). Dalam penelitian ini menguji kadar Nitrogen, Fosfor, Kalium, Karbon, dan tingkat pH dalam pupuk cair organik dari air bakso rebus. Data yang diperoleh dari penelitian ini dianalisis dengan menggunakan Rancangan Acak Lengkap dan uji lanjutan Duncan. Hasil penambahan aktivator EM4 dan punuk pisang MOL pada pembuatan pupuk cair organik dari air rebusan bakso menunjukkan tidak ada pengaruh yang signifikan $(\mathrm{P}>0,05)$ pada $\mathrm{N}, \mathrm{K}$, dan tingkat $\mathrm{pH}$ pada pupuk. Hasil penelitian menunjukkan pengaruh yang signifikan $(\mathrm{P}<0,05)$ pada konten $\mathrm{P}$ pupuk. Konten $\mathrm{C}$ tertinggi ditemukan di $\mathrm{P} 2$, sedangkan rasio $\mathrm{C} / \mathrm{N}$ tertinggi ditemukan di P0.
\end{abstract}

Kata kunci: aktivator, EM4, mikroorganisme lokal, pupuk organik cair

\section{INTRODUCTION}

Waste from the processing of meatballs every day is getting faster because meatballs are one of the favorite foods among the people and are accessible in the manufacturing process. This is supported by the increasing development of the meatball business in Rogojampi sub-district. Waste from boiled meatballs that are not utilized will be discharged directly into the sewer. Waste from the remaining meatball stew still contains high enough organic ingredients such as protein, fat, sodium carbohydrates, and potassium.

Organic liquid fertilizer is fertilizer derived from animal or vegetable waste that has undergone a fermentation process of utilization of meatball stew water waste as one of the main ingredients in making organic liquid fertilizer. Use of meatball stew water waste can be applied directly to the plant or decomposed first. The meatballs of boiled water will undergo a process of decomposition of organic matter so that it 
becomes a compound that is simple and easily absorbed by plants. The method of decomposition of organic compounds is assisted by adding activator substances.

The activators used in this study were EM4 and local microorganisms banana humps. Banana humps have the potential to be used as a source of Local Microorganisms because the nutrients in the banana hump can function as a food source for microbes to develop appropriately. In addition to local microorganisms, banana humps serve as antibiotic substances, capable of producing phosphate solvent bacteria that play a role in nitrification and denitrification, and can remodel organic compounds (Suhastyo, 2013). According to Kesuwaningwati (2017), the use of banana humps as decomposers of oil palm empty fruit bunch compost is higher in phosphorus and potassium content than compost with EM4 decomposers. Liquid organic fertilizer comes from waste of tilapia fish offal with the addition of Local Microorganisms banana humps maximum value to volume variations of Local Microorganisms for nitrogen $(\mathrm{N})$ of $0.311 \%$ at addition of $100 \mathrm{ml}$ Local Microorganisms banana humps, phosphor $0.167 \%$ at addition of $150 \mathrm{ml}$ Local Microorganisms Banana humps and potassium $0.037 \%$ in addition of $150 \mathrm{ml}$ of local banana microorganism (Lepongbulan, 2017). Dewi (2016), in her study of 28 days aerobic composting process using Mac Donald's method of compost with leachate activator and Local Microorganism banana hump to accelerate composting time. Resulting in leachate addition of $20 \mathrm{ml} / \mathrm{kg}$ and Local Microorganisms as much as 5 $\mathrm{ml} / \mathrm{kg}$ accelerates composting of organic waste to 3 weeks, C / N 14.21.

Based on this background, we conducted a study with the aim to determine the effect of microorganisms in EM4 and local microorganisms on the quality of organic liquid fertilizer and the impact of the length of time it takes for bacteria to degrade the content in meatball cooking water so that it can affect the availability of nutrients in organic liquid fertilizer.

\section{MATERIALS AND METHODS}

This research was carried out at the Livestock Product Processing Technology, Politeknik Negeri Banyuwangi. The research was conducted from April to June 2019. The tools used in this study included: $1 \mathrm{~L}$ cup glass, $50 \mathrm{ml}$ measuring cup, $\mathrm{pH}$ meter, plastic drum, weighing scale, bucket, knife, filter, Erlenmeyer, destination, spectrometer, pumpkin kjedahl, Instrument Atomic Absorption Spectrophotometer (AAS), Conway Indicator, and $\mathrm{pH}$ meter. The materials used in this study were meatball gravy, kepok banana hump, plantain bulb, ambon banana hump, rice water, brown sugar, EM4, molasses, $\mathrm{K} 2 \mathrm{CrO} 7, \mathrm{H} 2 \mathrm{SO} 4$, Aquades, ferroin, $\mathrm{FeSO} 4, \mathrm{NaOH}$, boric acid, $\mathrm{HCl}$, solution Ammonium Molybdate, NH4OAC, and buffer solution. This study used a completely randomized design analysis (CRD) consisting of 4 treatments and three replications to obtain 12 experimental units. The treatments in this study were: P0 (EM4), P1 (Local Microorganism from Kepok banana hump), P2 (Local Microorganism from Ambon banana hump), P3 (Local Microorganism from Raja banana hump).

The First Process of Making Local Microorganisms (LM) : Stages in the manufacture of Local Microorganisms from Banana Stumps. Prepare Local Microorganisms in the form of each $1 \mathrm{~kg}$ bunch of bananas finely ground and then put in a bucket. Mix $100 \mathrm{ml}$ of molasses and 1 liter of rice washing water then stir until smooth and put the lid on the bottle. Wait for the 7-day fermentation process.

The Process of making organic liquid fertilizers : In this study plastic jerry cans were used as a container to make organic liquid fertilizer from meatball sauce waste, the material used in this study came from boiled meatball water which is a waste from making meatballs. For each plastic, jerry can fill with 5 liters of meatball sauce. Then the activator liquid EM4 (Effective Microorganism 4) and Local Microorganisms were prepared banana hump (kepok, raja, and 
ambon) which served to help speed up the decomposition process.

Variation of the addition of $20 \mathrm{ml}$ EM4 volume and from Local Microorganism banana bunches as much as $20 \mathrm{ml}$ in each sample. Then stir it flat in a plastic jar and close it tightly and then ferment it for 20 days. The sample obtained will be analyzed the content of $\mathrm{N}, \mathrm{P}, \mathrm{K}, \mathrm{C}$, and $\mathrm{pH}$. Each uses the micro Kjeldahl method (for $\mathrm{N}$ ), spectrophotometer (P), Instrument Atomic Absorption Spectrophotometer (AAS) (for $\mathrm{K}$ ), and walked and black methods for analysis (C).

The data obtained were analyzed using variance analysis of variance (ANOVA). If there are significant differences between treatments, then it is followed by Duncan's multiple range test (Mattjik dan Sumertajaya, 2006).

\section{RESULTS AND DISCUSSION}

The results of the nitrogen content test on organic liquid fertilizer from the stew of meatball with banana hump activator did not show any significant differences (P) 0.05). Based on table 1 shows that $\mathrm{P} 2$ treatment has the highest average Nitrogen content, which is 0.1043 . The lowest average value of $\mathrm{N}$ content is found in treatment $\mathrm{P} 0$, with an average value of 0.0763 . The test results show that the use of banana hump activators has a higher $\mathrm{N}$ content when compared with the use of EM4 activators. According to Karyono (2017), the use of banana hump activators can increase the $\mathrm{N}$ content of fertilizers because banana humps have many buds containing gibberellins and cytokinins, which are growth regulators.
Local microorganisms from banana weevils have protein nutrient content; the use of local organisms from banana weevils will increase the $\mathrm{N}$ content of the organic fertilizer. $\mathrm{N}$ levels in fertilizers were produced through the decomposition of organic matter by microorganisms; the $\mathrm{N}$ content in fertilizers will affect decomposing organisms because they are essential compounds in the formation of cell protoplasms. According to Lakitan (2002), Nitrogen is one of the constituent elements of chlorophyll. Chlorophyll is a pigment needed as absorbent sunlight used in photosynthesis.

If $\mathrm{N}$ increases, chlorophyll also increases, so photosynthates produced and accumulated to plant growth also grow. The high and low nitrogen content is influenced by the protein content in the material. According to Suhastyo (2013) in banana humps there are microorganisms of the genus Bacillus, the genus Bacillus genus has different abilities including being able to overhaul organic compounds, able to produce antibiotics, play a role in nitrification and denitrification so that it can help process nitrogen formation. The $\mathrm{N}$ content in organic fertilizers is not fixed and depends on the material, how to compost, and how to make it. According to Cesaria et al. (2010), one of the factors that influence the $\mathrm{N}$ content in the composting process is the water content in the material. Nitrogen can react with water to form $\mathrm{NO}^{3-}$ and $\mathrm{H}{ }^{+}$compounds. $\mathrm{NO}^{3-}$ compounds have properties easily dissolved by water so that with a high moisture content can dissolve $\mathrm{NO}^{3-}$ compounds. $\mathrm{NO}^{3-}$ can be lost through evaporation because it changes into $\mathrm{N}_{2}$ and $\mathrm{N}_{2} \mathrm{O}$ compounds.

Table 1. Levels of Nitrogen Phosphorus, Potassium and fertilizer $\mathrm{pH}$ Levels

\begin{tabular}{lcccc}
\hline Parameter & \multicolumn{4}{c}{ Treatments } \\
\cline { 2 - 5 } & $\mathrm{P} 0$ & $\mathrm{P} 1$ & $\mathrm{P} 2$ & $\mathrm{P} 3$ \\
\hline Nitrogen & $0,0763 \pm 0,0067$ & $0,0900 \pm 0,0095$ & $0,1043 \pm 0,0302$ & $0,094 \pm 0,113$ \\
Phosphor & $0,0203 \pm 0,0015^{\mathrm{c}}$ & $0,0243 \pm 0,0015^{\mathrm{b}}$ & $0,0230 \pm 0,0010^{\mathrm{b}}$ & $0,0273 \pm 0,0015^{\mathrm{a}}$ \\
Potassium & $0,0526 \pm 0,0046$ & $0,0583 \pm 0,0040$ & $0,0633 \pm 0,0046$ & $0,0613 \pm 0,0057$ \\
pH & $7,5733 \pm 0,2742$ & $7,7533 \pm 0,2602$ & $7,7166 \pm 0,1050$ & $7,7358 \pm 0,0173$ \\
\hline Note : P0 (EM4), P1 (Local Microorganism from Kepok banana hump), P2 (Local Microorganism from Ambon \\
\multicolumn{4}{c}{ banana hump), P3 (Local Microorganism from Raja banana hump). The numbers followed by the same } \\
letters on the same line mean that they are not significant at the level of 1\%
\end{tabular}


The results of the phosphorus level test on organic liquid fertilizer from the stew of meatball with banana hump activator showed a significant difference $(\mathrm{P}<0.05)$. In table 1, it could be seen that treatment $\mathrm{P} 3$ has the highest average value of phosphorus content when compared with other treatments, which is equal to 0.0273 . The lowest average amount of phosphorus content is found in treatment $\mathrm{P} 0$, which is equivalent to 0.0203 . According to Karyono (2017) in banana humps, there are also microorganisms that play a role in the process of decomposing organic matter, especially in the process of phosphate dissolution. Organisms that play a role in forming phosphorus in fertilizers are Aspergillus niger.

According to the results of the research by Maningsih and Anas (1996), Aspergillus niger can increase the solubility of $\mathrm{P}$ from $\mathrm{A}_{1} \mathrm{PO}_{4}$ by $13.5 \%$ and can increase $\mathrm{P}$ solubility in Ultisol soil $30.4 \%$ compared to control. Some species of the genus Aspergillus have a higher ability to dissolve phosphate bound compared to bacteria. Phosphorus in fertilizer could be found in the form of $\mathrm{P}_{2} \mathrm{O}_{5}$, which was located at the end of the decomposition process. According to Hidayati et al., (2011), phosphorus compost has two forms, namely inorganic and organic shapes like nucleic acids, chitin, and lecithin. Phosphorus is used by microorganisms to process cell formation using enzyme phosphatase (Stofella and Khan, 2011).

The test results of potassium levels on organic liquid fertilizer from the stew of meatball with banana hump activator did not show any significant differences ( $\mathrm{P}>0.05$ ). In Table 1 it can be seen that treatment P2 has the highest average value of potassium content which is equal to 0.06330 , while the average amount of the lowest potassium content is in treatment $\mathrm{P} 0$ which is similar to 0.0526. According to Christie (2004), the cause of differences in potassium levels in fertilizers could is caused by $P$ solvent bacteria such as Bacillus mucilaginous.

According to Karyono (2017), the content of $\mathrm{K}$ elements in fertilizers was influenced by the weathering of organic matter contained in the compost. Potassium compounds are compounds produced by the metabolism of microorganisms. Microorganisms use free $\mathrm{K}^{+}$ions present in the material (Agustina, 2004). Organisms used potassium as a catalyst in the process of metabolism (Hidayati et al., 2004). Optimal decomposition activities cause $\mathrm{K}$ elements to break down into available forms. Potassium is bound and stored in cells of microorganisms and will be re-released when degraded (Putri et al., 2014). Salisbury and Ross (1995) state that K elements play an essential role in opening and closing stomata and acting as activators of various enzymes involved in protein and carbohydrate synthesis. If $\mathrm{K}$ increases, carbohydrates also increase so that it can be used to improve plant growth. The $\mathrm{K}$ content produced in this study is by the standard standards of the government based on ministerial regulations agriculture No. 2 / pert / HK.060 / 2/2006, which is the content $<5 \%$.

The results of the $\mathrm{pH}$ test on organic liquid fertilizer from a stew of meatball with banana hump activator did not show a significant difference; it could be seen from the sig value that is equal to 0.312 . Based on table 1 shows that treatment $\mathrm{P} 2$ has the highest average $\mathrm{pH}$ value, which is 7.7533 . The lowest average value of $\mathrm{pH}$ was found in treatment P0, with an average value of 7.5733. The results showed that the use of banana hump activators had the same $\mathrm{pH}$ range as the use of EM4 activators, namely the $\mathrm{pH}$ range $4-8$. This was by the research conducted by Ekawandani (2009) that vegetable waste fermentation with EM4 fermentation for 20 days produced $\mathrm{pH} 7$. The $\mathrm{pH}$ content in this study is by the range of ethical $\mathrm{pH}$ values for fertilizer. A suitable $\mathrm{pH}$ range for liquid organic fertilizer is around 6.5 - 7.5 (Indriani 2002). The level of acidity is related to environmental conditions or habitat of these living microorganisms. If the acidity or $\mathrm{pH}$ level is not by the optimal $\mathrm{pH}$ of enzyme activity, it will affect the metabolic activity of microorganisms. 
Consequently, microorganisms cannot grow and develop optimally (Adi, 2018).

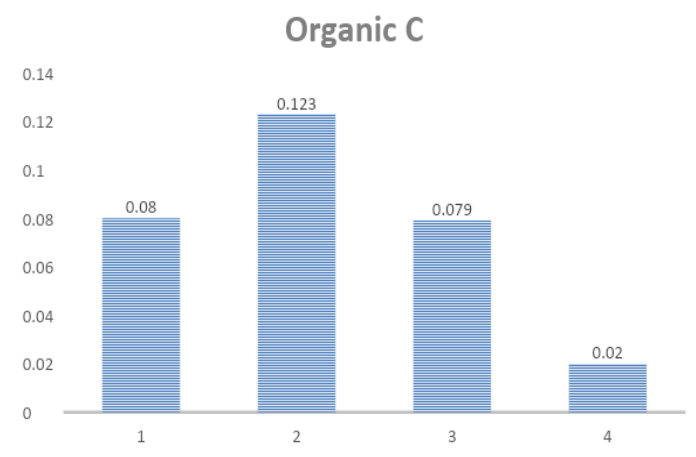

Figure 1. Graph of organic C content of fertilizer.

In figure 1, the use of kepok banana hump activator has the highest $\mathrm{C}$ organic value when compared to the use of other activators. Based on Figure 1, it can be seen that the use of kepok banana hump activator has the highest $\mathrm{C}$ organic value when compared with the use of other activators. Microorganisms can use the function of carbon in kepok bananas as an energy source to compile cellulose material for microbial cells by freeing $\mathrm{CO} 2$ and other substances that evaporate besides the composting process as an energy source (Mifthakul, 2013).

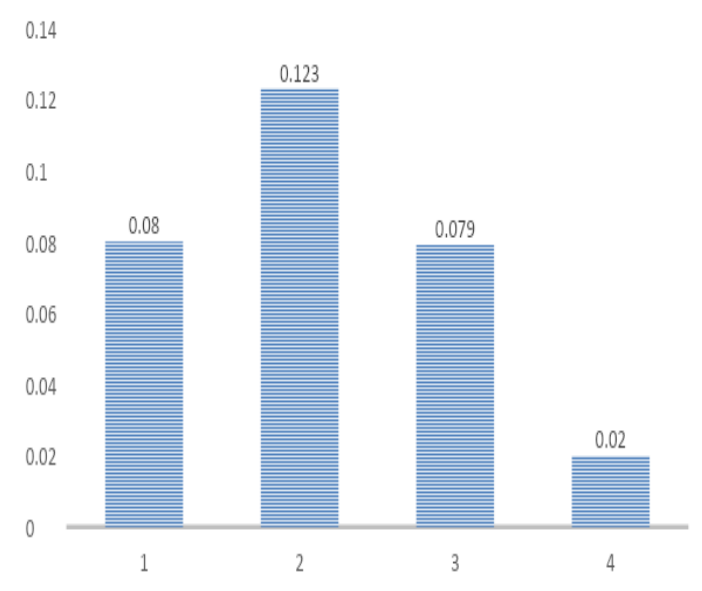

Figure 2. Graph of fertilizer C / N ratio.

The $\mathrm{C} / \mathrm{N}$ ratio is the ratio of the levels of elements $\mathrm{C}$ and $\mathrm{N}$ elements found in the material. The fermentation process in fertilizers aims to reduce the $\mathrm{C} / \mathrm{N}$ ratio of fermented ingredients. The fermentation process in fertilizers is expected to reduce the $\mathrm{C} / \mathrm{N}$ ratio of fertilizers so that the rate of $\mathrm{C} /$ $\mathrm{N}$ to compost is equal to the value of the $\mathrm{C} /$ $\mathrm{N}$ ratio on the soil. If the ratio of $\mathrm{C} / \mathrm{N}$ to fertilizer is the same as the ratio of $\mathrm{C} / \mathrm{N}$ to ground, the nutrients in fertilizers were more easily absorbed by the soil. According to Karyono (2017), the most critical factor in the fertilizer manufacturing process is the $\mathrm{C} /$ $\mathrm{N}$ ratio, the $\mathrm{C} / \mathrm{N}$ ratio in fertilizers affects the activity of microorganisms that require carbon as a source of energy and nitrogen as a source of protein to form cells.

In Figure 2, it can be seen that in treatment $\mathrm{P} 1$, the $\mathrm{C} / \mathrm{N}$ Organic ratio is higher when compared to the use of other activators. The value of the $\mathrm{C} / \mathrm{N}$ ratio in treatment $\mathrm{P} 1$ is 1 . The $\mathrm{C} / \mathrm{N}$ ratio is influenced by the content of $\mathrm{N}$ and $\mathrm{C}$ in the material. The difference in the $\mathrm{C} / \mathrm{N}$ ratio in fertilizers is due to the decomposition of element $\mathrm{C}$ bonds in materials carried out by microorganisms. Element $\mathrm{C}$ is needed by microbes as an energy source and is released in the form of $\mathrm{CO} 2$ so that it causes element $\mathrm{C}$ in the material to decrease, element $\mathrm{N}$ is used by microorganisms to synthesize proteins and formation of cells and when microbes die $\mathrm{N}$ drive will be released again until the amount is fixed or increasing (Nugroho, 2018). The $\mathrm{C} / \mathrm{N}$ ratio in this study is low when compared with the Minister of Agriculture Regulation No: 70 of 2011. The results of the study showed a range of values of $0.199-1$ that value is very far when compared with the Minister of Agriculture Regulation No: 70 of 2011, which is $15-25$.

\section{CONCLUSION}

Utilization of local microorganism activators originating from the banana hump can increase phosphorus content.

\section{REFERENCE}

Agustina. 2004. Dasar Nutrisi Tanaman. Reneka Cipta. Jakarta. 54 hal. 
Cesaria, R.Y., Wirosoedarmo, R., dan Suharto, B. 2010. Pengaruh penggunaan starter terhadap kualitas fermentasi limbah cair tapioka sebagai alternatif pupuk cair. Jurnal Sumberdaya Alam dan Lingkungan. 12 (2): $8-14$

Christie. 2006. Decomposition of Silicate Minerals by Bacillus mucilaginous In Liquid Cultures. Environ Geochem and Health Journal. 28: 133-140.

Ekawandani, N dan A.K. Arini. 2018. Pengomposan sampah organik (kubis dan kulit pisang) dengan menggunakan EM 4. TEDC Jurnal. 12(1): $38-43$.

Hidayati, A. Yuli, Tb. Benito A. Kurniani, E. T. Marlina dan E. Harlina. 2011. Kualitas Pupuk Cair Hasil Feses Sapi Potong Menggunakan Saccaromyces cereviceae. Jurnal Ilmu Ternak. 11(2): 104-107.

Indriani. 2002. Petunjuk Penggunaan Pupuk. Penebar Swadaya, Jakarta.

Karyono, T., Maksudi, dan Yatno. 2017. Penambahan Aktivator MOL Bonggol Pisang dan EM4 Dalam Campuran Feses Sapi Potong dan Kulit Kopi terhadap Kualitas Kompos dan Hasil Panen Pertama Rumput Setaria (Setaria splendida Stapf). Skripsi. Fakultas Pertanian Universitas Musi Rawas Lubuklinggau.

Kesuwaningwati, R. 2015. Penggunaan MOL bonggol pisang (Musa paradisiaca) sebagai dekomposer untuk pengomposan tandan kosong kelapa sawit. Jurnal. Ziraa'ah. 40 (1): 40-45.

Lakitan, B. 2002. Dasar-Dasar Fisiologi Tumbuhan. Raja Grafindo Persada. Jakarta.
Maningsih, G., dan I. Anas. 1996. Peranan Aspergillus Niger dan Bahan Organik Dalam Transformasi $\mathrm{P}$ Anorganik Tanah. Dalam Pemberitaan Penelitian Tanah dan Pupuk. Badan Litbang Pertanian. Puslittanak. 14:31-36.

Mashita, N., E. Sulistyawati, dan N. C. Devi. 2008. Pengaruh Agen Dekomposer terhadap Hasil Kualitas Hasil Pengomposan Sampah Organik Rumah Tangga. Sekolah Ilmu dan Teknologi Hayati, ITB, Bandung. (Seminar Nasional Penelitian Lingkungan).

Mattjik, A.A dan M. Sumertajaya. 2002. Perancangan Percobaan dan Aplikasi SAS dan Minitab. Jilid I. Edisi ke 2. Bogor (ID): IPB Press.

Miftakhul, H.S., Suyono, dan P.R. Wikandari. 2013. Efektivitas kandungan unsur hara pada pupuk kandang hasil fermentasi kotoran ayam terhadap pertumbuhan tanaman terung (Solanum melongena L.). Unesa Journal of Chemistry. 2(1): $131-136$.

Ratrina, P.W., W. F. Maruf dan E. Nurcahya. 2014. Pengaruh Penggunaan Bioaktivator EM4 dan Penambahan Daun Lamtoro terhadap Spesifikasi Pupuk Organik Cair Rumput Laut. Jurnal Pengolahan dan Bioteknologi Perikanan. 3 (3): 82-87.

Stofella P.J. dan B.A. Khan. 2001. Compost Utilization in Horticulture Systems. Lewis Phublisher. USA. 56 p.

Suhastyo, A. A., I. Anas, dan D. A. Santoso. 2013. Studi mikrobiologi kimia mikroorganisme lokal (MOL) yang digunakan pada budidaya padi metode SRI (Sytem of Rice Intensification). $\begin{array}{llll}\text { Jurnal } & \text { Sainteks. } 10 & \text { (2):29-39. }\end{array}$ 